九州大学学術情報リポジトリ

Kyushu University Institutional Repository

\title{
A Study of the Limiting Factors of Dairy Production Development in Hano i Vietnam -A Cace Study in Phudong and Vinhngoc Communes-
}

Quach, Thi Xuan

Labotatory of Quantitative Analysis of Agribusiness Organization, Division of Industrial Organization of Agribusiness, Departmentof Agricultural and Resource Economics, Graduate School of Bioresource and Bioenvironmental Sciences, Kyushu University

Kawaguchi, Tsunemasa

https://doi.org/10.5109/4518

出版情報：九州大学大学院農学研究院紀要. 47 (2)，pp.477-501，2003-02-01. Faculty of Agriculture, Kyushu University バージョン：

権利関係 : 


\title{
A Study on the Limiting Factors of Dairy Production Development in Hanoi Vietnam - A Case Study in Phudong and Vinhngoc Communes -
}

\author{
QUACH, Thi Xuan* and KAWAGUCHI, Tsunemasa
}

\author{
Laboratory of Quantitative Analysis of Agribusiness Organization, Division of Industrial \\ Organization of Agribusiness, Department of Agricultural and Resource Economics \\ Faculty of Agriculture, Kyushu University, Fukuoka 812-8581 \\ (Received October 30, 2002 and accepted November 7, 2002)
}

\begin{abstract}
The economy of Vietnam has recently been restructuring, and dairy production is considered to develop with high potentiality to meet the increasing market demand for milk and milk products in nationwide, especially in the city (Phan 2000, IFPRI 2001, Nguyen 2001). Vietnam government also plans to increase the proportion of domestic milk production over total milk consumption up from $9.8 \%$ in 1999 to $32 \%$ in 2010 (MARD 2001).

In the suburb of Hanoi, dairy production has been started since 1990, and it is expected to solve the difficulties facing farmers to improve dairy production here. The objective of this study is, a) to investigate the present situation of dairy production in Hanoi, b) to identify problems limiting the expansion of dairy production in the study area from the standpoint of farmers and government, and c) to give some recommendations to improve dairy production in Hanoi. A case study method was applied in this paper, and Phudong (Gialam district) and Vinhngoc (Donganh district) commune were selected as research sites. Forty six dairy households and twelve dairy households in Phudong and Vinhngoc, respectively, were randomly selected in the list of total dairy households of the communes.

Result of survey shows that dairy farmers in Hanoi have been facing some outstanding problems that restraint them from starting and expanding dairy production. Those are, problem of shortage of green fodder, problem of lack of capital, problem of breeding and cow diseases and etc.. Based on this survey, we make some recommendations about master plan of land, farmer's access to credit, supply of good dairy input services (especially breeding and veterinary services), establishment of new dairy cooperatives, and extension programs to train new dairy farmers.
\end{abstract}

\section{INTRODUCTION}

\subsection{Rationale}

Vietnam has been known as a poor country with its economy mainly based on agriculture. However, since the launch of the renovation policy of the Vietnamese Communist Party towards the "market oriented economy", everything has been gradually changed. Economic restructuring is underway in a positive direction. GDP contribution of the agricultural sector in the national economy has been declining in percentage. Even though gross output of agriculture has been increasing at the rate of 3 to $4 \%$ per year (GSO 2002), the share of crop cultivation has been becoming smaller in comparison with those

\footnotetext{
* Laboratory of Quantitative Analysis of Agribusiness Organization, Division of Industrial Organization of Agribusiness, Department of Agricultural and Resource Economics, Graduate School of Bio-resource and Bioenvironmental Sciences, Kyushu University, Fukuoka 812-8581.
} 
of livestock and agricultural services.

The same trend can be found in Hanoi even though it is capital city (table 1.1). Total population of Hanoi up to $31^{\text {st }}$ Dec. 2001 is 2812.1 thousand. Population density is about 3053 persons $/ \mathrm{km}^{2}$. These figures in the suburbs of the city are 1305.8 thousand, and $1561 \mathrm{pers} / \mathrm{km}^{2}$, respectively. In the suburbs, household incomes are highly dependent on agricultural production. In 2001, about 675,100 people were engaged in agriculture, accounting for $51.7 \%$ of the population of the region. Total gross output of agriculture of Hanoi has been increasing, but it is a small change, from VND 1244.4 billions in 2000 to VND 1252.8 billion in 2001 (at constant 1994 price).

Table 1.1. Gross output of agriculture in Hanoi

(Unit: Bill. VND at constant 1994 price)

\begin{tabular}{rrrrrrrr}
\hline Year & Total & $\begin{array}{c}\text { Crop } \\
\text { Cultivation }\end{array}$ & $\%$ & Livestock & $\%$ & Services & $\%$ \\
\hline 1995 & 963.164 & 633.076 & $65.73 \%$ & 330.088 & $34.27 \%$ & 0 & $0.00 \%$ \\
1998 & 1127.557 & 705.814 & $62.60 \%$ & 396.285 & $35.15 \%$ & 25.458 & $2.26 \%$ \\
1999 & 1181.248 & 729.383 & $61.75 \%$ & 423.409 & $35.84 \%$ & 28.456 & $2.41 \%$ \\
2000 & 1244.380 & 763.906 & $61.39 \%$ & 446.446 & $35.88 \%$ & 34.028 & $2.73 \%$ \\
2001 & 1252.789 & 733.483 & $58.55 \%$ & 481.639 & $38.45 \%$ & 37.667 & $3.01 \%$ \\
\hline
\end{tabular}

Source: Hanoi statistical yearbook 2001 (page 169)

Gross output share of crop cultivation has been decreasing to $58.55 \%$ in 2001 from $61.39 \%$ in 2000 , while share of livestock has been increasing to $38.45 \%$ in 2001 from $35.88 \%$ in 2000 . Demand for livestock products has been rapidly increasing in Hanoi, and livestock brings farmers a higher benefit under this situation. Therefore, livestock has been rapidly expanding and diversifying, including silkworm raising, cow rearing, fish raising and poultry-farming. Of this dairy production is now becoming popular in 4 of 5 districts in Hanoi city. Income from selling raw milk is a main and biggest income source of dairy households.

Hanoi is not a dominant area for dairy production compared to the rest of Vietnam. The number of dairy cows in the whole country was 30,000 by late 1999 , growing to more than 32,000 by June 2000 . Of these, more than 13,000 are lactating cows. The majority of cows are in Southern provinces, accounting for $85 \%$. The cow herd in Hanoi was about $3.75 \%$ of national cow herd in 1999 . However, it accounted for $27 \%$ of total cows in the northern Vietnam in the same year (MARD 2001)

Since 1998, with the support of technique and capital from Vietnam-Belgium dairy project, many farmers have invested in dairy production. As a result, total number of dairy households reached a figure of 408 in 1999 and up to 660 in 2001 (table 1.2). Correspondingly, the cow herd of Hanoi has also been increasing from 1019 heads in 1998 to 1288 heads in 1999 and 1650 heads in 2001. It can be asked whether this tendency will continue in the coming years. Is it possible to develop a producing zone of raw milk in Hanoi to meet the increasing market demands on raw milk? What are the limiting factors? A study on dairy production in Hanoi will be necessary to answer these questions. 
Table 1.2. Cow herd in Hanoi

\begin{tabular}{clrrrrrr}
\hline Year & & \multirow{2}{*}{1995} & 1998 & 1999 & 2000 & 2001 & 2002 \\
No. of $\mathrm{HH}$ & (HH) & & 219 & 408 & 577 & 660 & $987^{*}$ \\
Cow herd & (head) & \multirow{2}{*}{1266} & 1019 & 1288 & 1442 & 1650 & $2158^{*}$ \\
Grow rate & $(\%)$ & & & 26.4 & 11.96 & 14.42 & $30.79^{*}$ \\
\hline
\end{tabular}

Source: Hanoi statistical yearbook 2001 ( $^{*}=$ estimated figure, HH=Household)

\subsection{Objectives of the study}

The specific objectives of this paper are as follows:

1. To investigate the present situation of dairy production in Hanoi.

2. To identify problems limiting the expansion of dairy production in the study area from the standpoint of farmers and government.

3. To give some recommendations to improve dairy production in Hanoi.

\subsection{Method of the study}

The study is multidimensional; hence, quantitative and qualitative information needs to be obtained through literature review, available records, questionnaire survey, interviews, and through participatory rural appraisal. The diverse viewpoints were analyzed with attention focused on farmer's view as no one know better their living and working condition, needs and aspirations. Case study method is the best way for these purposes. So we make use of case study method in this study.

The survey was carried out in Phudong (Gialam district) and Vinhngoc (Donganh district) commune. Forty six dairy households in Phudong and twelve dairy households in Vinhngoc were randomly selected in the list of total dairy households of the communes. Phudong will represent communes with high number of cows and dairy households, while Vinhngoc will represent communes that have recently been involved in dairy production and the number of dairy households is still few.

\section{NATURAL AND SOCIO-ECONOMIC CONDITIONS IN THE STUDY AREA}

\subsection{Natural and socio-economic conditions in the study area}

Two communes-Phudong and Vinhngoc-have been selected as study site, one in Gialam district and the other in Donganh district. These are two out of five districts in the suburbs of Hanoi city. They have the common characteristics of the Red River delta.

PhuDong is located in the northeast of Gialam district, about $15 \mathrm{~km}$ far from Gialam town and about $23 \mathrm{~km}$ far from Hanoi center. Total natural land area in PhuDong is 1165.65 ha separated in two kinds of land by the dyke of Duong River. Land inside the dyke is used for cultivating rice (winter-spring and summer-autumn rice) and other sub-crops, such as maize, soybean, potato, and sweet-potato. Phudong has $40 \%$ of cultivated area being alluvial-ground used for growing maize, mulberry and grass.

Total natural area of Vinhngoc is 559 ha. Of this 470.5 ha is agricultural land, occupying $84 \%$ of natural land. Like Phudong, the main crop of Vinhngoc is rice planted twice a year on an area of $350.5 \mathrm{ha}$. Apart from maize and mulberry, farmers in Vinhngoc also 
grow some industrial crops, such as groundnuts and sugarcane.

Dairy farming has been started in Phudong commune since 1990. At present there are 460 households rearing cow, accounting for $17 \%$ of total households in the commune (table 2.1). Vinhngoc is also one of communes which a higher number of cows compared to other communes in Donganh district, but dairy farmers here have only 3 years experience. Number of dairy households is equal to about one-tenth of those in Phudong. It is estimated that a herd of 955 cows in Phudong will produce 1,342 tonnes of raw milk equivalent to VND 4,548 million in 2002. Corresponding estimated figures are 81 cows, 222 tonnes and VND 748 million in Vinhngoc, respectively.

Table 2.1. Cow herd in the selected communes

\begin{tabular}{lcccc}
\hline & $\begin{array}{c}\text { Dairy households } \\
\text { (HH) }\end{array}$ & $\begin{array}{c}\text { Cow herd } \\
\text { (head) }\end{array}$ & $\begin{array}{c}\text { Total milk } \\
\text { (tonnes) }\end{array}$ & $\begin{array}{c}\text { Value } \\
\left(10^{6} \text { VND) }\right.\end{array}$ \\
\hline PhuDong & & & & \\
1999 & 188 & 438 & 693.371 & 2389 \\
2000 & 280 & 625 & 863.514 & 2979 \\
2001 & 419 & 869 & $1,277.000$ & 4391 \\
2002 & 460 & 955 & 1342.000 & 4548 \\
Growth rate & $36 \%$ & $30.5 \%$ & $25.8 \%$ & $25.2 \%$ \\
VinhNgoc & & & & \\
2002 & 46 & 81 & 222.463 & 748 \\
\hline
\end{tabular}

Source: survey 2002

\subsection{Background of the sampled households \\ 2.2.1 Family size}

On average the family size of the sampled households is 4.55 . This figure is 4.6 in Phudong, a little higher than 4.5 of Vinhngoc. Nearly $93 \%$ of households have 4 or 5 family members (table 2.2). The size of 3 was found in one family in Vinhngoc (1.7\%), and the size of 6 was found in 3 families in Phudong (5.2\%) only. Households having three generations or more than two children are commonly found in those household with more than 4 members.

Table 2.2. Number of Households in different sizes

\begin{tabular}{lccccccccccc}
\hline \multicolumn{1}{c}{ Commune } & Total & \multicolumn{2}{c}{ 3 Pers. } & \multicolumn{2}{c}{ 4 Pers. } & \multicolumn{2}{c}{5 Pers. } & \multicolumn{2}{c}{6 Pers. } \\
\hline & No. of HH & $\begin{array}{l}\text { No. of } \\
\text { HH }\end{array}$ & $\begin{array}{l}\text { No. of } \\
\text { HH }\end{array}$ & $\begin{array}{l}\text { No. of } \\
\text { HH }\end{array}$ & $\begin{array}{l}\text { No. of } \\
\text { HH }\end{array}$ & $\%$ \\
\hline $\begin{array}{l}\text { Phudong } \\
\text { Vinhngoc }\end{array}$ & 46 & 0 & 0 & 22 & 48 & 21 & 45 & 3 & 7 \\
Total & 12 & 1 & 9 & 4 & 33 & 7 & 58 & 0 & 0 \\
\hline
\end{tabular}

Source: Survey 2002 


\subsubsection{Family labor}

In average, the number of the main laborers of households interviewed is about half of family size, ranging from 2.17 to 2.4. Each household has at least 2 members at the working age and doing on-farm activities as full-time job, namely 2 main laborers. The others are elders and children helping with odd jobs, or those who are doing off-farm or non-farm activities. The average age of the main laborers in the study area is 38 years-old, ranging from 26 to 51 . At this age, farmers are strong and patient enough to do dairy works.

Results of survey show positive indicators about education level of the main laborers (table 2.3). About $70 \%$ of the main laborers had finished secondary school and $22 \%$ of them had passed their high school exams. The number of laborers with higher education level is quite few, however, the number of laborers at primary level is not many, only $4 \%$. In general, dairy farmers in the study area are able to learn and apply the new techniques in dairy production.

Table 2.3. Education level of the main on-farm laborers

\begin{tabular}{lcccccccccr}
\hline Commune & Total & \multicolumn{2}{c}{ Primary } & \multicolumn{2}{c}{ Secondary } & \multicolumn{2}{c}{ High level } & \multicolumn{2}{c}{ Higher level } \\
\cline { 3 - 9 } & $\begin{array}{c}\text { Main } \\
\text { laborers }\end{array}$ & $\begin{array}{l}\text { Number } \\
\text { of pers. }\end{array}$ & $\%$ & $\begin{array}{l}\text { Number } \\
\text { of pers. }\end{array}$ & $\%$ & $\begin{array}{l}\text { Number } \\
\text { of pers. }\end{array}$ & $\begin{array}{l}\text { Number } \\
\text { of pers. }\end{array}$ & $\%$ \\
\hline Phudong & 110 & 6 & 5 & 77 & 70 & 24 & 21.6 & 3 & 3 \\
Vinhngoc & 26 & 0 & 0 & 17 & 65.4 & 6 & 23.1 & 3 & 11.5 \\
Total & 136 & 6 & 4.4 & 94 & 69.1 & 30 & 22 & 6 & 4.4 \\
\hline
\end{tabular}

Source: Survey 2002

On average, with the existing conditions of production, one cow needs 2.5 to 4 working hours of one laborer per day, depending on dairy farm size. For example if a household has one main laborer rearing one cow, he will have to spend 4 hours a day to do all the dairy works. If he rears 2 cows, he will only have to spend total 6 hours a day. The optimum dairy farm size is dependent, of course, on labor resources and many other input factors.

Dairy farmers in Phudong have longer experiences than those in Vinhngoc (table 2.4). Percentages of dairy household having less than 3 years of experiences are $24 \%$ and $63.1 \%$ in Phudong and Vinhngoc, respectively. There are only $4.3 \%$ of total households in Vinhngoc having 6 to 9 years of experiences; while $24 \%$ of total households in Phudong

Table 2.4. Experience on dairy farming

\begin{tabular}{lrrrrr}
\hline Commune & \multicolumn{3}{c}{ Dairy households classified by years of experience } & \multicolumn{2}{c}{ Average experiences } \\
& $1<\mathrm{E}<3$ & $3=\mathrm{E}<6$ & $6=\mathrm{E}<9$ & $\mathrm{E}>=9$ & of sampled housholds (years) \\
Phudong & 24 & 28 & 24 & 24 & 6 \\
Vinhngoc & 63.1 & 32.6 & 4.3 & 0 & 3 \\
\hline
\end{tabular}

Source: Survey 2002 
have been rearing cows for more than 9 years of experience. In average, farmers in phudong have 6 years and farmers in Vinhngoc have 3 years in dairy experience.

\subsubsection{Labor division}

The survey's result on labor division shows that there are two parts of labor in one family, one does on-farm activities and the other does off-farm activities. $64 \%$ and $50 \%$ of households investigated in Phudong and Vinhngoc, respectively, have one or more members who are engaged in off-farm employment or even away for migrant labor. Most of them are teenagers who are not interested in farming. Some of them are self-employed workers doing off-farm activities in their villages, some others are working away from home.

Like most other rural regions of Vietnam, a mixed farming system has also been applied in the study area. That system includes rice cultivation, dairy production, silkworm and fish raising. Men and women, boys and girls share their family works. The labor division between them is flexible and dependent on their abilities, their health and their usable time. Men are often found to be responsible for the heavy and important works such as milking, taking care of cows at calving or breeding, and seeking credit. Women work longer than men, from 10 to 12 hours a day. They are not only housewives. They play a crucial role in farming. They can do most of the work done by men such as feeding, milking, collecting grass, cleaning the barn and participating in extension programs. In Phudong and Vinhngoc, women are responsible for $55 \%$ and $57 \%$ (source: survey 2002) of everyday work on the whole, respectively. Children are often seen to graze cows half of the day when they are off school or to help their parents in cooking and tidying up.

According to the survey, $56 \%$ of households in Phudong are headed by men. The corresponding figure in Vinhngoc reached nearly $92 \%$. A household head is the person who makes the final decisions in a family. The remaining members are dependent. Being dependent persons, women have no right to decide family's expenditure even if they work much and make a bigger contribution to household's income, and so they seem to benefit less than men.

\subsubsection{Land holding}

In the study area, land is granted for each household in terms of family size with duration of 20 years. Each person was allocated $360 \mathrm{~m}^{2}(1 \mathrm{sao})$ of paddy land and $100 \mathrm{~m}^{2}$ of alluvial land in 1995. Because of the long-term use, families having children born after 1995 can get no more land, but others hold the same area after their family member's death. This causes an unevenness and certain difficulties for young couple after marriage. At present, on average, each household holds about $1,600 \mathrm{~m}^{2}$ of land for rice, and

Table 2.5. Average land holding of surveyed households

\begin{tabular}{lrrr}
\hline \multicolumn{2}{c}{ Items } & Phudong & \multicolumn{2}{c}{ Vinhngoc } \\
Paddy land & $\left(\mathrm{m}^{2} / \mathrm{HH}\right)$ & 1580 & 1620 \\
Alluvial land & $\left(\mathrm{m}^{2} / \mathrm{HH}\right)$ & 475 & 450 \\
Rented-in land & $\left(\mathrm{m}^{2} / \mathrm{HH}\right)$ & 1000 & 550 \\
Total resident land & $\left(\mathrm{m}^{2} / \mathrm{HH}\right)$ & 233 & 361 \\
\hline
\end{tabular}

Source: Survey 2002 
$460 \mathrm{~m}^{2}$ of alluvial ground for maize, mulberry or grass (table 2.5). To increase the productivity, farmers also grow maize or soybean in the paddy field in between two rice crops.

Land rented-in was found in $80 \%$ of total households interviewed in Phudong. The corresponding ratio for Vinhngoc was around 50\%. Rented-in land area ranges from $360 \mathrm{~m}^{2}$ to $1,500 \mathrm{~m}^{2}$ per household. All the respondents grow maize or grass for cows in their rented land. It is important to note that higher land demand corresponds to higher number of dairy households.

A common characteristic of the farming system in the north of Vietnam is that arable land is allocated to farmers in many different plots. On average, each household has 5 plots in Vinhngoc and 8 plots in Phudong. It is very difficult for any farmer to grow other kinds of crop individually on the paddy land. This is a factor restraining the development of dairy production in the study area.

\subsubsection{Household' assets}

In the study area, people traditionally have a permanent living-house, a separated cook-house or kitchen, a barn for cows, sometimes a hen-house and a pigsty as well. All were built within an average area of $233 \mathrm{~m}^{2}$ and $361 \mathrm{~m}^{2}$ in Phudong and Vinhngoc, respectively. There is no land left for a garden.

Dairy farmers in Phudong as well as in Vinhngoc keep their cows in the tie-stall barn. Because of the limited resident land, the distance between their house and the barn is quite near, ranging from 3 to $15 \mathrm{~m}$. Most barns were upgraded pigsties. They are not wide enough, only 3 or $4 \mathrm{~m}^{2}$ per cow. The barns were usually designed for 3 cows. The barns for more than 5 cows were not found in Phudong but in Vinhngoc. Some rich farmers have just applied the biogas technique to construct new barns with bio-digester below. The percentage of sampled households having bio-digester is $30 \%$ in Phudong. In Vinhngoc, this percentage is higher, at $40 \%$. The reason for this difference is that dairy farmers in Vinhngoc were carefully trained before rearing cows, even though dairy farming here started later than Phudong. This is a good lesson to learn.

There is no milking machine in the study area, and farmers milk by hands. 10 or 15 liter-buckets and cans are commonly used for containing milk before transproting to the receiving station. Each household has at least one bucket and one can be provided by the Vietnam-Belgium project or by milk collectors.

Every dairy household has fans for cooling cows in the summer and a water pump for cleaning barn. The farmers also use some traditional tools for sanitation. In Phudong $84 \%$ of the investigated households have at least one motorbike and $88 \%$ own a bicycle, and in Vinhngoc that is $60 \%$ and $83 \%$, respectively. The household without any vehicles

Table 2.6. Asset of surveyed households

\begin{tabular}{llrrrrrrr}
\hline \multicolumn{2}{c}{ Commune } & Biogas & $\begin{array}{c}\text { Buckets, } \\
\text { cans }\end{array}$ & Motorbike & bicycle & $\begin{array}{r}\text { Water } \\
\text { pump }\end{array}$ & Wagon & rear-car \\
\hline \multirow{2}{*}{ Phudong (unit) } & 14 & 46 & 39 & 40 & 46 & 0 & 0 \\
& (\%) & 30 & 100 & 84 & 88 & 100 & 0 & 0 \\
Vinhngoc & (unit) & 5 & 12 & 7 & 10 & 12 & 1 & 3 \\
& (\%) & 40 & 100 & 60 & 83 & 100 & 8.3 & 25 \\
\hline
\end{tabular}

Source: Survey 2002 
was not found in Phudong but there was one in Vinhngoc (table 2.6).

Due to the increasing needs on culture and spirit as well as demand on information exchange of farmers, television is an important facility given highest priority for spending. Up to now, nearly $100 \%$ of households own a color television. It is a useful channel for farmers to learn and apply the new advanced technologies to their farming. A small percentage of the sampled households own other facilities such as thresher combine and tiller for cultivation, or mill and grinder for off-farm activities.

\subsubsection{Household's income sources}

Like many other rural Vietnamese households, households in the study area receive income from a variety of sources, including crop cultivation, dairy production, silkworm and fish raising, poultry-farming and ornamental plants (table 2.7). $60.87 \%$ of households in Phudong and 50\% in Vinhngoc have one or more laborers doing off-farm and/or non-farm activities in order to diversify their income sources. Each off-farm or non-farm laborer has been earning 6 to 10 million VND a year.

Table 2.7. Main activities of sampled households

\begin{tabular}{lrrrr}
\hline \multirow{2}{*}{ Items } & \multicolumn{2}{c}{ Phudong } & \multicolumn{2}{c}{ Vinhngoc } \\
\cline { 2 - 5 } & No of HH & Percentage & Number & Percentage \\
\hline Dairy production & 46 & $100.00 \%$ & 12 & $100.00 \%$ \\
Crop cultivation & 45 & $97.83 \%$ & 11 & $91.67 \%$ \\
Off or/and non-farm activities & 28 & $60.87 \%$ & 6 & $50.00 \%$ \\
Silkworm production & 1 & $2.17 \%$ & 3 & $25.00 \%$ \\
& & & & \\
\hline
\end{tabular}

Source: Survey 2002

Among dairy households investigated, $97.83 \%$ in Phudong and $91.67 \%$ in Vinhngoc receive a small but stable income from crop cultivation, mainly from rice production. The rotation of rice-rice-winter maize or soybean on paddy field is often found in the intensive farming pattern. The alluvial land is also cultivated at least twice a year. Total estimated income from crop cultivation is about VND 2 million per year, accounting for $40 \%$ of total incomes of households rearing $1 \mathrm{cow}$ and only $10 \%$ of total income of households having 3 cows. Income from dairy production has always been biggest in households not involved in off-farm and/or non-farm activities. Without risks, one dairy cow could bring an income of more than VND 5 million a year.

\subsubsection{Access to credit}

Because of a high capital requirement for buying cows, most of dairy farmers have sought to credit at the initial stage of their dairy farming. According to the survey, $35 \%$ of sampled households borrowed money from "hunger eradication and poverty reduction project" through Women Union (table 2.8). Every farmer wanted to get credit from this source because of the low interest rate, but only a few, who could prove their income to be under the poverty line, could obtain. There is $25 \%$ of sampled households used bank credit, properly Agricultural Banks or Banks for the Poor. About 30\% of farmers said that the interest rates of the above credit sources were acceptable but they sometimes required complicated procedures and took time. The duration of loan was not as long and 
Table 2.8. Access to credit of farmers in the study area

\begin{tabular}{lcccccc}
\hline \multicolumn{1}{c}{ Items } & Banks & Dairy coop. & Relatives & Friends & Lenders & $\begin{array}{c}\text { Women } \\
\text { Union }\end{array}$ \\
\hline \% HH using credit & 25 & - & 16 & 16 & 8 & 35 \\
Amount (mill.VND) & 5 & - & $3 \sim 6$ & $2 \sim 10$ & $2 \sim 4$ & 5 \\
Duration (years) & $2 \sim 5$ & - & $5 \sim 10$ & $5 \sim 10$ & unlimited & $2 \sim 5$ \\
Interest (\%/month) & $0.7 \sim 1$ & - & 0 & 0 & $1 \sim 2$ & $0.3 \sim 0.7$ \\
Loan demanding & & \multicolumn{5}{c}{ VND 20 mill./household } \\
Phudong & As much as possible \\
Vinhngoc & \multicolumn{5}{c}{} \\
\hline
\end{tabular}

Source: survey 2002

the amount of loan was not as much as farmers expected. However, these are two main sources of credit for farmers in the study area.

It is reported that $32 \%$ of sampled households also have used some informal sources of credit, including relatives and friends. The greatest advantage of these sources is that the interest rate was at zero level. Beside, farmers could borrow a flexible amount in a longer duration. Farmers had to seek credit from lenders in the village if it was impossible for them to borrow money from all the other sources mentioned above. On average, each dairy household owns a debt of VND 10 millions with an interest rate of $1 \%$ per month.

\subsubsection{Access to information}

Most dairy farmers obtained technical assistances from the Vietnam-Belgium project from 1998 to 2000. Dairy farmers in Phudong and Vinhngoc were trained in the basic knowledge of rearing cows through the extension programs, such as how to feed, how to milk, how to recognize cow diseases and etc.

For new dairy farmers, however, the most important and effective channel to learn is the relevant lessons from their neighbors. Farmers share their experience in many different and simple ways. They can learn from observing what happened to the cows of their neighbors. Farmers can also receive their own knowledge for free through conversations with others on the way to market, at milk collecting stations or in the field. Other useful channels for farmers to train themselves is through mass media like television, radio and newspaper.

\section{DAIRY FARMING}

\subsection{Characteristics of cow herd}

More than four breeds of cows are being reared in the study area. They are crossbred Shindhi, F1 1/2 blood of HF, F2 3/4 blood of HF, F3 5/8 blood of HF, F3 3/8 blood of HF and other breed (table 3.1). According to Thuong (1995), they are all suitable to the climate of Hanoi because they have a maximum $75 \%$ blood of pure HF.

Obviously, the higher percentage of HF blood the cow has, the higher the yield of milk it produces. However, a cow with higher percentage of HF blood was found to be easily affected by climate environment. With these lessons learned, most of dairy farmers in 
Table 3.1. Crossing formula of some cow breeds reared in Hanoi

\begin{tabular}{ll}
\hline Type of breeds & \multicolumn{1}{c}{ Crossing formula } \\
\hline Crossbred Sindhi & Domestic female cow $\times$ Red Sindhi bull \\
F1 $1 / 2$ blood of HF & Crossbred Sindhi Female cow $\times$ HF bull \\
F2 $3 / 4$ blood of HF & F1 $1 / 2$ blood of HF female cow $\times$ HF bull \\
F3 5/8 blood of HF & F2 $3 / 4$ blood of HF female cow $\times$ F1 1/2 blood of HF bull \\
F3 3/8 blood of HF & F2 $3 / 4$ blood of HF female cow $\times$ Red Sindhi bull \\
\hline
\end{tabular}

Source: Survey 2002

Hanoi have been rearing cows crossbred with HF, mainly F2 $3 / 4$ blood of HF, and F3 5/8 blood of HF.

Total sampled cows are 140 heads in Phudong and 31 heads in Vinhngoc. Of which, $54.29 \%$ and $64.52 \%$ are F2 $3 / 4$ blood of $\mathrm{HF}, 35 \%$ and $32 \%$ are F3 5/8 blood of HF in Phudong and Vinhngoc, respectively (table 3.2). These two breeds are about $400 \mathrm{~kg}$ in weight, and most of them were artificially inseminated for the first time by age of 15 to 20 months. They were older than 2 years old at the first calving. Approximately, F2 3/4 and F3 5/8 have similar features with a lactating period of 305 days/year, and $13 \mathrm{~kg}$ fresh milk/day.

Table 3.2. Structure of cow herd in terms of breed

\begin{tabular}{clccccc}
\hline \multicolumn{2}{c}{ Location } & Total & F1 & F2 (3/4) & F3 (5/8) & Other \\
\hline \multirow{2}{*}{ Phudong } & (Head) & 140 & 11 & 76 & 49 & 4 \\
& (\%) & 100 & 7.86 & 54.29 & 35 & 2.86 \\
Vinhngoc & (Head) & 31 & 1 & 20 & 10 & 0 \\
& (\%) & 100 & 3.23 & 64.52 & 32.26 & 0 \\
\hline
\end{tabular}

Source: survey 2002

$80 \%$ and $78.26 \%$ of sampled households have at least 1 lactating cow in Phudong and Vinhngoc, respectively (table 3.3). The remainders are rearing calves or heifer. They are properly new dairy farmers. Total number of lactating cows accounts for $68 \%$ of total sampled cows in Phudong and 55\% in Vinhngoc. The percentage of calves and heifers in Vinhngoc is rather higher than that in Phudong.

Table 3.3. Structure of cow herd in terms of age

\begin{tabular}{lccccc}
\hline Location & $\begin{array}{c}\text { HH with at least 1 } \\
\text { lacta. cows (\%) }\end{array}$ & $\begin{array}{c}\text { Lactating cows } \\
\text { (head) }\end{array}$ & $\%$ & $\begin{array}{c}\text { Calves and heifers } \\
\text { (head) }\end{array}$ & $\%$ \\
\hline Phudong & 80 & 54 & 68 & 26 & 32 \\
Vinhngoc & 78.26 & 17 & 55 & 14 & 45 \\
\hline
\end{tabular}

Source: survey 2002 
Compared to other districts of Hanoi and other provinces like Hatay and HCM city, dairy farm size of Hanoi is very small, ranging from 2 to 3 heads per household on the average (table 3.4). These figures are 5 in Thanhtri district of Hanoi and 4.5 in Hatay. It is possible to note that the more experience the dairy farmers have, the larger the dairy farm size they manage. Dairy farmers in Phudong has started to rear milk cows 7 years earlier than those in Vinhngoc, that's why the dairy farm size here is 3, while in Vinhngoc it is 2 only. The percentage of size with three heads was highest in Phudong, reaching nearly $40 \%$, while in Vinhngoc corresponding figure was $17 \%$ with $50 \%$ of dairy households owning two cows. The survey results also show that there were 11 households, accounting for $24 \%$ in Phudong, managing sizes of 4 cows or more. While in Vinhngoc, there was only 1 household with a size of 10 cows, however, manager of which is a cow broker.

Table 3.4. Cow herds in different sizes

\begin{tabular}{llccccc}
\hline & & Size of 1 & Size of 2 & Size of 3 & Size of 4 & Larger size \\
\hline \multirow{2}{*}{ Phudong } & (No. of $\mathrm{HH}$ ) & 6 & 11 & 18 & 4 & 7 \\
& (\%) & 13.04 & 23.91 & 39.13 & 8.7 & 15.22 \\
Vinhngoc & (No. of $\mathrm{HH})$ & 3 & 6 & 2 & 0 & 1 \\
& $(\%)$ & 25 & 50 & 17 & 0 & 8 \\
\hline
\end{tabular}

Source: survey 2002

At present, even though the dairy farm size is very small, it is suitable size for $63.1 \%$ of households in Phudong and $41.6 \%$ of households in Vinhngoc (table 3.5). Even $4.3 \%$ of household in Phudong said that they have too many cows. Giving these answers, those dairy farmers were considering about their limited input factors such as lack of green fodder, shortage of labor, small barn, and other basic conditions that make marginal revenue smaller if they enlarge their dairy farm size.

Table 3.5. Intension to change dairy farm size of surveyed households

\begin{tabular}{ccccc}
\hline & Unit & Too few & Enough & Too many \\
\hline \multirow{2}{*}{ Phudong } & (No. of HH) & 15 & 29 & 2 \\
& $(\%)$ & 32.6 & 63.1 & 4.3 \\
Vinhngoc & (No. of HH) & 7 & 5 & 0 \\
& $(\%)$ & 58.4 & 41.6 & 0 \\
\hline
\end{tabular}

Source: Survey 2002

It is interesting to know that among dairy households with suitable size, $50 \%$ of them are rearing 3 cows, and about $30 \%$ of them are rearing more than 3 cows. For this reason, it is possible to give a preliminary conclusion that the optimal dairy farm size is 3 cows/households or more in Hanoi in present conditions.

Nevertheless, the percentages of households wishing to enlarge the size are remarkable, $32.6 \%$ in Phudong and $58.4 \%$ in Vinhngoc. In these households some available resources have not been economically used, for example labor force. What they need is 
capital and what they expect is female calves born by their own cows.

\subsection{Feeding and feed cost}

Feed composition for a cow varies in terms of age, milk yield of cow, locally available resources and seasons of a year. Condensed feed, roughage, mineral and salt are indispensable components for a lactating cow. Farmers in Phudong usually graze their cows on the dykes of Duong River for 2 hours a day (Picture 1).

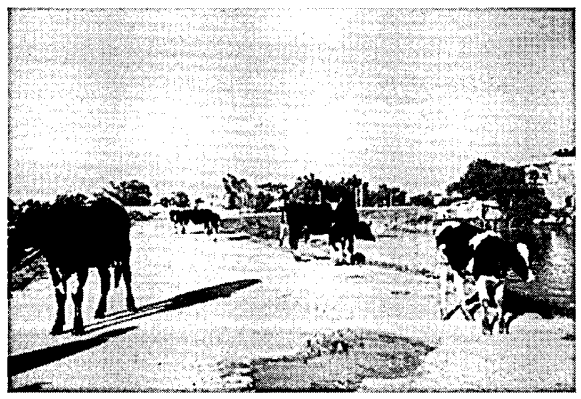

Picture 1. Cow grazing

Dairy farmers in Phudong use rice bran, corn, soybean and brewery's byproduct as concentrates. Slight difference was observed in Vinhngoc where molasses and mixed bran was used instead of soybean and brewery's byproduct. 100\% of brewery's byproduct, molasses and mixed bran were bought, but $20 \%$ of rice bran, corn and soybean is self-supplied by farmers.

For roughage, dry fodder like hay and straw has been used only when green fodder is not available. There are many kinds of green fodder. These are mainly natural grass collected from embankments and river banks in the surrounding areas within a radius of $60 \mathrm{~km}$. Other sources of green fodder maybe pennisetum, sweet potato forage or young maize grown by farmers but these sources meet only $20 \%$ of total roughage needed. Stalk of harvested maize or sugarcane leaves are also used to feed cows if available.

Feeding green fodder is a habit of farmers in the study area. $98 \%$ of farmers in Phudong did not make silage but hay; even not knowing what fermentation is. In Vinhngoc, dairy farmers understood about silage but they said it was unnecessary to ensile, they prefer feeding fresh grass.

In the study area, farmers often feed cows with a mixed ration. Ration for a pregnant heifer at the beginning stage is about 35 to $40 \mathrm{~kg}$ of pennisetum. $1 \mathrm{~kg}$ of molasses and $35 \mathrm{~kg}$ of pennisetum could be ration for a pregnant heifer at the stage of 190-220 day pregnancy. The ration will be increased to $1.7 \mathrm{~kg}$ molasses and $35 \mathrm{~kg}$ grass when the fetus is 220-250 days. After this stage pregnant heifer will be fed the same ration of $35 \mathrm{~kg}$ grass and $2 \mathrm{~kg}$ molasses and $0.6 \mathrm{~kg}$ cassava or $1.6 \mathrm{~kg}$ corn and $0.5 \mathrm{~kg}$ rice bran.

Most farmers were trained to feed their lactating cows based on milk yield. There are two kinds of ration. The basis ration is to maintain the first $5 \mathrm{~kg}$ of milk and the productive ration calculated from ratio 1:2 between concentrates and milk quantity for the amount of milk over $5 \mathrm{~kg}$ (table 3.6). 
Table 3.6. Ration for lactating cow

\begin{tabular}{llclcc}
\hline \multicolumn{1}{c}{ Ration } & Unit & Grass & Corn & Rice bran & Mixed bran \\
\hline Basis ration (1) & $(\mathrm{kg})$ & 35 & 1 & 1.25 & 0.25 \\
Basis ration (2) & $(\mathrm{kg})$ & 40 & 0.75 & 0.50 & 0.25 \\
Productive ration 1 & $(\mathrm{kg})$ & & 0.50 & 0.25 & 0.25 \\
Productive ration 2 & $(\mathrm{kg})$ & & 0.60 & 0.15 & 0.25 \\
Productive ration 3 & $(\mathrm{kg})$ & & 0.4 & 0.2 & \\
\hline
\end{tabular}

Source: Pual Pozy, Ban 2001

In theory, dairy farmers should feed cows an exact quantity of feed basing on the milk yield per day. They should record milk yield and measure feed fed. In practice, however, rations are dependent on farmer's attitude and on what and how much feed they can afford. Usually, farmers feed their cows all of the green fodder they collected within a day. Due to the dominance of F2 breed with average milk yield of $13 \mathrm{~kg}$ in the study area, feed cost will be calculated here for this breed only (table 3.7).

Table 3.7. Feed cost for F2 cow, weight $400 \mathrm{~kg}$ and $13 \mathrm{~kg}$ milk per day

\begin{tabular}{|c|c|c|c|c|c|}
\hline \multirow[b]{2}{*}{ No Kinds of feed } & \multicolumn{2}{|c|}{ Phudong } & \multicolumn{3}{|c|}{ Vinhngoc } \\
\hline & $\begin{array}{c}\text { Price } \\
\text { VND/kg }\end{array}$ & $\begin{array}{c}\text { Quantity } \\
\mathrm{kg}\end{array}$ & $\begin{array}{l}\text { Value } \\
\text { VND }\end{array}$ & $\begin{array}{c}\text { Quantity } \\
\mathrm{kg}\end{array}$ & $\begin{array}{l}\text { Value } \\
\text { VND }\end{array}$ \\
\hline \multicolumn{6}{|l|}{ Constrates } \\
\hline 1 Rice bran & 1,500 & 2.05 & 3,075 & 2.05 & 3,075 \\
\hline 2 corn & 2,500 & 2.6 & 6,500 & 2.6 & 6,500 \\
\hline 3 Soybean & 6,000 & 0.25 & 1,500 & & 0 \\
\hline 4 Guyo-68 & 5,000 & & 0 & 0.25 & 1,250 \\
\hline 5 Brewery's by product & 600 & 5.6 & 3,360 & & 0 \\
\hline 6 Molasses & 1,500 & & 0 & 2.5 & 3,750 \\
\hline Roughage & & & & & 0 \\
\hline 7 Green fodder & 200 & 40 & 8,000 & 40 & 8,000 \\
\hline \multicolumn{6}{|l|}{8 Dry fodder } \\
\hline \multicolumn{6}{|l|}{ Others } \\
\hline 9 Mineral & 10,000 & 0.05 & 500 & 0.05 & 500 \\
\hline 10 Salt & 1,000 & 0.05 & 50 & 0.05 & 50 \\
\hline Feed cost per day in la & & & 22,985 & & 23,125 \\
\hline Total feed cost of lact & & & $7,010,425$ & & $7,053,125$ \\
\hline Total feed cost of lact & self-sup & grass & $4,570,425$ & & $4,613,125$ \\
\hline
\end{tabular}

Source: survey 2002

With the prices at the time the survey was carried out, $45 \%$ of households reported that concentrates prices were expensive, while the rest said they were reasonable compared to milk price. Average feed cost for F2 lactating cow per day during the lactating period is about VND 22,985 in Phudong and VND 23,125 in Vinhngoc, accounting for $52 \sim 57 \%$ of revenue received by farmers. The corresponding figures are VND 14,985, VND 15,125 and $32 \sim 37 \%$ if labor cost for grass is not included (table 3.8 ). Total 
Table 3.8. Feed cost

\begin{tabular}{|c|c|c|c|c|c|}
\hline \multirow[t]{2}{*}{ Items } & & \multicolumn{2}{|c|}{$\begin{array}{c}\text { Feed cost } \\
\text { (purchased grass) }\end{array}$} & \multicolumn{2}{|c|}{$\begin{array}{c}\text { Feed cost } \\
\text { (self-supplied grass) }\end{array}$} \\
\hline & & Phudong & Vinhngoc & Phudong & Vinhngoc \\
\hline \multicolumn{6}{|l|}{ Drurinng the dry period } \\
\hline $60-30$ days before calving & (VND/day) & 10,750 & 10,550 & 2,750 & 2,550 \\
\hline $30-0$ days before calving & (VND/day) & 12,750 & 12,500 & 4,750 & 4,500 \\
\hline Sub-total & (VND) & 705,000 & 691,500 & 225,000 & 211,500 \\
\hline Druring the lactating period & (VND/day) & 22,985 & 23,125 & 14,985 & 15,125 \\
\hline Sub-total & (VND) & $7,010,425$ & $7,053,125$ & $4,570,425$ & $4,613,125$ \\
\hline Total & (VND/year) & $7,715,425$ & $\mathbf{7 , 7 4 4 , 6 2 5}$ & $\mathbf{4 , 7 9 5 , 4 2 5}$ & $\mathbf{4 , 8 2 4 , 6 2 5}$ \\
\hline
\end{tabular}

Source: survey 2002

estimated feed cost with purchased green fodder is VND 7,715,425 in Phudong and VND $7,744,625$ in Vinhngoc. If green fodder is self-supplied then total feed costs per year in two places are also nearly the same, roughly VND 4.8 million.

\subsection{Milking and marketing fresh milk}

Milking is carried out twice a day. On most of the farms, milking takes place between 5 and 7 in the morning and between 6 and 7 in the evening. There were not milking machines. The farmers milk by hand. It takes them about 15 minutes for a man to milk a cow. Two hind legs of cow are tied during milking to avoid milk loss. Farmers use buckets for milking, and pour milk from them into cans (picture 2).

People in the study area have no habit of drinking fresh milk. It is reported that about $50 \%$ of sampled households have self-consumed a very small part of total milk they produced a day. They did not drink milk every day but occasionally or only when they had poor quality milk unsold. Another small amount of milk was also sold to several customers in the village. The farmers sell all the milk remained to the collectors at the receiving stations because they have not learnt any technique to process milk into other milk products (picture 3).

There are four milk receiving stations in Phudong-Gialam and one in

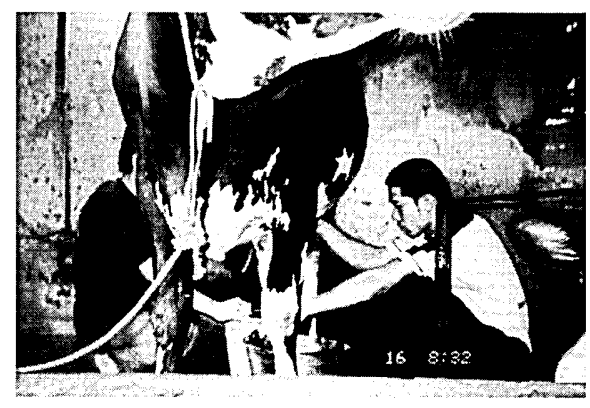

Picture 2. Milking

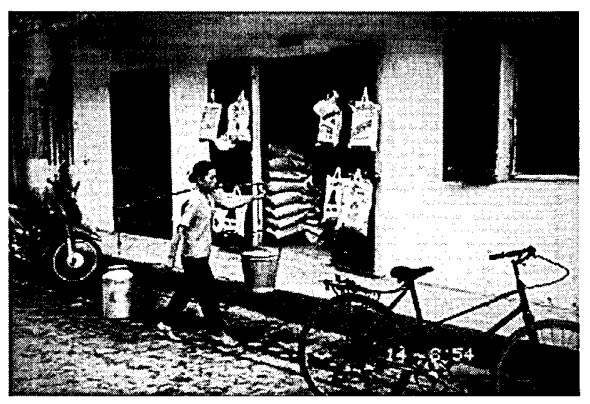

Picture 3. Milk delivered by farmers 
Vinhngoc-Donganh. Collectors in Phudong signed a commercial contract with Vinamilk factory located in Gialam, while collector in Vinhngoc sell all milk to Nestle Company located in Hatay. Farmers carry cans of milk to the receiving stations on foot, by bicycle or motorbike. In Phudong, farmers chose the favorite or the nearest station to sell their fresh milk. There is no difference about price among four stations here, even though there is one station managed by Phudong Dairy Cooperative. Farmers receive payment in terms of quantity and quality of milk measured and analyzed by collectors in the presence of farmers (picture 4, 5,6).

Dairy farmers in Vinhngoc have no choice except selling their milk at Vinhngoc receiving station belonging to Donganh People's Committee. The collector is responsible for managing all the activities of the station from procurement, selling to analyzing milk quality. The analyzing facility funded by Vietnam and Belgium project gives the same indicators with measurement system of Nestle Company, but the problem here is that

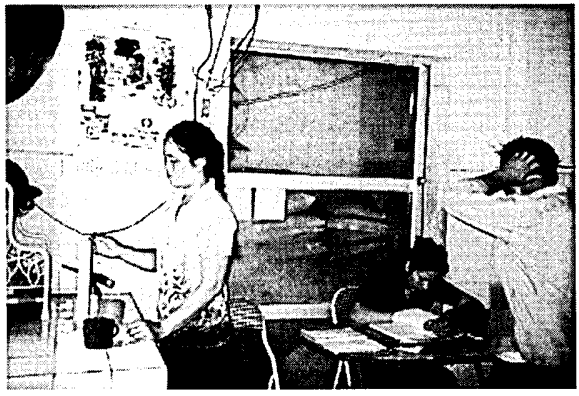

Picture 4. Checking milk quantity + quality

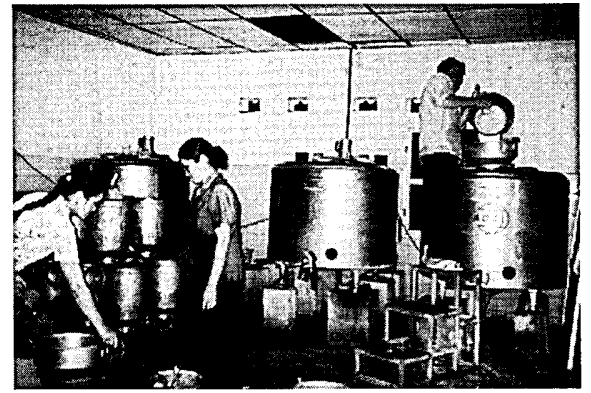

Picture 5. Milk storing

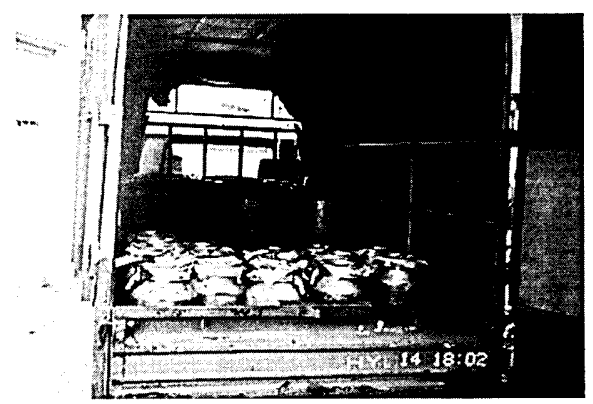

Picture 6. Transporting to milk factory

Table 3.9. Milk price paid to farmers by collectors in Phudong based on specific gravity

\begin{tabular}{lcccc}
\hline Specific gravity & $10256-10260$ & $10261-10265$ & $10266-10269$ & $>10270$ \\
Price VND/kg & 2800 & 2900 & 3000 & 3100 \\
\hline
\end{tabular}

Source: Survey 2002 
analyzing process is done without the presence of farmers. According to the survey, milk prices paid to farmers ranged from VND 2,800 to VND 3,350/kg, about VND 100 to VND 500 lower than prices paid to collector by milk factories (table 3.9).

\subsection{Labor cost}

According to the survey, there were $10 \%$ of dairy households hiring laborers. Most of them are working part-time, mainly in the harvesting seasons. The only case of hired laborer working for full-time job was found in Vinhngoc. This laborer gets three meals a day and a payment of VND 3,600,000 per year, about VND 10,000 per day.

One of reasons encouraging farmers to rear cows is to utilize their family labor force. In between crops, all the works are done by the main laborers of the family. While during the harvesting, elders and children are important forces to help main laborers to finish every works in time. Among dairy-related works, collecting green fodder takes much time, about one hour per cow if time on the way is not included. Most of dairy farmers have to go very far, $20 \mathrm{~km}$ to $60 \mathrm{~km}$ away from their village, by bicycle or motorbike to collect natural grass. This work is done in the morning and grazing is done in the late afternoon. Non-farm and off-farm laborers, sometimes, help their family with feeding, cleaning, milking or transporting milk because these works are done in the early morning and evening.

One laborer needs to spend 4 hours, 5.5 hours and 7 hours a day to care for a dairy farm of size 1, 2 and 3 cows, respectively. The larger the dairy farm size is, the smaller the average working time on a cow will be. Man-day equivalent working time per cow per year is dependent upon farm size, estimated figure ranging from 100 days to 185 days (table 3.10).

Table 3.10. Man-day Equivalent working time

\begin{tabular}{|c|c|c|c|c|c|c|c|c|}
\hline \multirow{2}{*}{ Activities } & & \multicolumn{3}{|c|}{ Working time } & \multirow{2}{*}{$\begin{array}{c}\text { No. of } \\
\text { time/day }\end{array}$} & \multicolumn{3}{|c|}{ Total } \\
\hline & & 1 cow & 2cows & 3cows & & 1 cow & 2cows & 3cows \\
\hline Feeding and cleaning & (Min.) & 10 & 15 & 20 & 2 & 20 & 30 & 40 \\
\hline Milking & (Min.) & 10 & 20 & 30 & 2 & 20 & 40 & 60 \\
\hline Milk transporting & (Min.) & 10 & 10 & 10 & 2 & 20 & 20 & 20 \\
\hline Collecting green fodder & (Min.) & 120 & 180 & 240 & 1 & 120 & 180 & 240 \\
\hline Grazing & (Min.) & 60 & 60 & 60 & 1 & 60 & 60 & 60 \\
\hline Total working time/day & (Min.) & & & & & 240 & 330 & 420 \\
\hline Total working time/year & (Min.) & & & & & 88800 & 116250 & 143700 \\
\hline Man-day equivalent & (days) & & & & - & 185 & 242 & 299 \\
\hline Man-days/cow & & & & & & 185 & 121 & 100 \\
\hline Man-days/cow if grass p & urchased & & & & & 91 & 114 & 137 \\
\hline
\end{tabular}

Source: survey 2002

\subsection{Breeding and veterinary cost}

On the average, interval of calving of cow in the study area is one year. Artificial insemination (AI), however, was successfully done at first time on $60 \%$ of sampled cows in Phudong and 50\% in Vinhngoc (table 3.11). Two or more times of artificial insemina- 
Table 3.11. Breeding and artificial insemination cost

\begin{tabular}{lccccccc}
\hline Locations & $\begin{array}{c}\text { \% of cows } \\
\text { with } \\
\text { one AI }\end{array}$ & $\begin{array}{c}\text { \% of cows } \\
\text { with } \\
\text { more than } \\
\text { one AI }\end{array}$ & $\begin{array}{c}\text { Average } \\
\text { breeding cost } \\
\text { per cow per } \\
\text { year (VND) }\end{array}$ & & \multicolumn{2}{c}{ Cost of AI /time (VND) } \\
\cline { 5 - 7 } & 60 & 40 & 100000 & 70000 & 50000 & 30000 \\
time & $\begin{array}{c}\text { Second } \\
\text { time }\end{array}$ & $\begin{array}{c}\text { Next } \\
\text { times }\end{array}$ \\
\hline Phudong & 50 & 50 & 110000 & 80000 & 60000 & 40000 \\
\hline
\end{tabular}

Source: Survey 2002

tion were needed for the rest. The reasons of artificial insemination's failure were not only because of physical condition of cows but also because of lack of well-experienced and enthusiastic veterinarians leading to a wrong (irrelevant) time of insemination.

Breeding cost is VND 70,000 for the first time. If it is failure, farmers will have to pay VND 50,000 for the second time, and VND 30000 for the next times in Phudong. This cost was VND 10,000 higher in Vinhngoc.

Similar to other animal, diseases happened to cows are quite often and by accident. Some dairy farmers have experienced on treating many kinds of disease, but the others have not. Diarrhea and dyspepsia are two kinds of diseases that happened to every cow with a highest incidence, twice a year on the average. Fortunately, dairy farmers know how to treat these diseases by themselves and the costs were not expensive, about VND 50,000 per time only. Cause of diarrhea and dyspepsia was feed fed. It was possibly that green fodder was collected at the area infected by pesticide recently sprayed. It was also because of mould concentrates or overfeeding.

Mastitis, retained placenta and fever were rarely happened, with an incidence of 0.4 , 0.4 and 0.2 , respectively, but sometimes they were very serious. Mastitis caused by inappropriate milking technique and careless cleaning nipples after milking of dairy farmers. Retained placenta happened at calving only, while fever accidentally occurred at any time. Climate changing or infectivity in blood is main causes of fever. Many cows recorded to die due to the serious fever. It, on the average, cost approximately VND 100,000, VND 200,000 and VND 500,000 for treatment of mastitis, retained placenta and fever each time, respectively (table 3.12 ).

Table 3.12. Diseases and treatment cost

\begin{tabular}{|c|c|c|c|c|c|c|}
\hline \multirow[t]{2}{*}{ Kinds of diseases } & \multicolumn{2}{|c|}{$\begin{array}{c}\% \text { of } \mathrm{HH} \text { having } \\
\text { experience }\end{array}$} & \multirow[t]{2}{*}{$\begin{array}{c}\text { Incidence/ } \\
\text { year/cow }\end{array}$} & \multirow[t]{2}{*}{$\begin{array}{c}\text { Cost/time } \\
\text { (VND) }\end{array}$} & \multicolumn{2}{|c|}{$\begin{array}{l}\% \text { of } \mathrm{HH} \text { having } \\
\text { cows died }\end{array}$} \\
\hline & Phudong & Vinhngoc & & & Phudong & Vinhngoc \\
\hline Mastitis & 28 & 25 & 0.4 & 100,000 & & \\
\hline Retained placenta & 28 & 17 & 0.4 & 200,000 & & \\
\hline Diarrhea & 28 & 33 & 2 & 50,000 & & \\
\hline Dyspepsia & 28 & 33 & 2 & 50,000 & & \\
\hline Fever & 40 & 50 & 0.2 & 500,000 & 32 & 25 \\
\hline Total cost per year & & & & 420,000 & & \\
\hline
\end{tabular}

Source: Survey 2002 


\subsection{Miscellaneous costs}

Miscellaneous costs are including cost for interest, electric, fuel and telephone charge. In average, each household with one cow have to pay VND 600 thousand for borrowing VND 5 millions with level of interest rate at $1 \%$ per month if they rear one cow (table 3.13). Among miscellaneous costs, fuel cost is the most expensive. It costs farmers about VND 5,000 to use a motorbike a day, corresponding to VND $1,825,000$. It is noted that farmers in Vinhngoc did not have to spend money on fuel for dairy production.

Table 3.13. Dairy miscellaneous cost per year

\begin{tabular}{lcrrr}
\hline \multicolumn{1}{c}{ Items } & Unit & 1 cow & 2 cows & 3 cows \\
\hline Interest cost & Thous.VND & 600 & 1200 & 1800 \\
Electric cost & Thous.VND & 365 & 400 & 500 \\
Fuel cost & Thous.VND & 1,825 & 1,825 & 1,825 \\
Telephone charge & Thours.VND & 24 & 48 & 72 \\
Other & Thous.VND & 200 & 250 & 300 \\
\hline Total & Thous.VND & 3,014 & 3,723 & 4,497 \\
\hline
\end{tabular}

Source: Surveyed 2002

\subsection{Fixed costs}

At present, price of cow is quite expensive, about VND 20 millions for an F2 cow of first pregnancy. Supposing that the economic life of cow is about 10 years, depreciation cost will be simply estimated by straight-line method, i.e. VND 2 millions per year (table 3.14). Some main fixed assets being depreciated are including barn, bio-digester, and motorbike. As mentioned above, a barn with a bio-digester costs about 5 millions and a motorbike costs VND 10 millions. The straight-line method is used again to estimate depreciation of fixed assets. In Vinhngoc, farmers did not use motorbike for collecting grass, so depreciation cost of fixed assets were VND 500,000 per cow per year, and a bit higher for household rearing 2 or 3 cows.

Table 3.14. Depreciation cost

\begin{tabular}{lcrcc}
\hline Items & 1 cow & 2 cows & 3 cows \\
\hline Depreciation cost & & 3,500 & 5,600 & 7,700 \\
Depreciation of cow & (Thous.VND) & 2,000 & 4,000 & 6,000 \\
Depreciation of fixed assets & (Thous.VND) & 1,500 & 1,600 & 1,700 \\
\hline
\end{tabular}

Source: Surveye 2002

\subsection{Income from dairy farming}

Income from dairy farming will be calculated in both communes: Phudong and Vinhngoc, by farm sizes of 1,2 and 3 heads, and by two cases of purchased and self-supplied grass. Some hypothesis will be used as follows. An F2 cow will produce $3965 \mathrm{~kg}$ of milk per year, and price of milk is VND 3,100 per kg. In useful life, a cow will give 10 
calves with the ratio of male and female is 1:1. A female calf will cost VND 4 millions and a male calf will cost VND 0.4 million if they are sold soon after calving. In average, farmers will obtain VND 2.2 million from selling calf (table 3.15). It is also supposed that farmers have to purchase $100 \%$ of concentrates. Excretion of cow will be discharged into bio-digester. One cow produces enough excretion for a $5 \mathrm{~m}^{3}$ bio-digester. The rest will be sold. Farmer will get VND 30,000 per month from saving gas cost, and VND 10,000 per cow per month from selling excretion.

Table 3.15. Cost-benefit of dairy production with purchased grass

Unit: Thous. VND

\begin{tabular}{lrrrrrr}
\hline Iterns & \multicolumn{3}{c}{ Phudong } & \multicolumn{3}{c}{ Vinhngoc } \\
\hline & 1 cow & 2 cows & 3 cows & 1 cow & 2 cows & 3 cows \\
\hline Benefit & $\mathbf{1 4 , 8 5 1 . 5}$ & $\mathbf{2 9 , 7 0 3 . 0}$ & $\mathbf{4 4 , 5 5 4 . 5}$ & $\mathbf{1 4 , 8 5 1 . 5}$ & $\mathbf{2 9 , 7 0 3 . 0}$ & $\mathbf{4 4 , 5 5 4 . 5}$ \\
Fresh milk & $12,291.5$ & $24,583.0$ & $36,874.5$ & $12,291.5$ & $24,583.0$ & $36,874.5$ \\
Calf & $2,200.0$ & $4,400.0$ & $6,600.0$ & $2,200.0$ & $4,400.0$ & $6,600.0$ \\
Manure & 360.0 & 480.0 & 600.0 & 360.0 & 480.0 & 600.0 \\
Cost & $\mathbf{1 3 , 8 3 4 . 4}$ & $\mathbf{2 5 , 1 0 8 . 8}$ & $\mathbf{3 6 , 4 4 8 . 2}$ & $\mathbf{1 3 , 8 5 3 . 6}$ & $\mathbf{2 5 , 1 5 7 . 2}$ & $\mathbf{3 6 , 5 2 5 . 8}$ \\
Fixed cost & $\mathbf{3 , 5 0 0 . 0}$ & $5,600.0$ & $7,700.0$ & $3,500.0$ & $5,600.0$ & $7,700.0$ \\
Depreciation of cow & $2,000.0$ & $4,000.0$ & $6,000.0$ & $2,000.0$ & $4,000.0$ & $6,000.0$ \\
Depreciation of fixed assest & $1,500.0$ & $1,600.0$ & $1,700.0$ & $1,500.0$ & $1,600.0$ & $1,700.0$ \\
Variable cost & $\mathbf{1 0 , 3 3 4 . 4}$ & $\mathbf{1 9 , 5 0 8 . 8}$ & $\mathbf{2 8 , 7 4 8 . 2}$ & $\mathbf{1 0 , 3 5 3 . 6}$ & $\mathbf{1 9 , 5 5 7 . 2}$ & $\mathbf{2 8 , 8 2 5 . 8}$ \\
Feed cost & $7,715.4$ & $15,430.8$ & $23,146.2$ & $7,744.6$ & $15,489.2$ & $23,233.8$ \\
Labor cost & 910.0 & $1,140.0$ & $1,370.0$ & 910.0 & $\mathbf{1 , 1 4 0 . 0}$ & $1,370.0$ \\
Breeding and veterinary cost & 520.0 & $1,040.0$ & $1,560.0$ & 510.0 & $1,030.0$ & $1,550.0$ \\
Miscellaneous costs & $1,189.0$ & $1,898.0$ & $2,672.0$ & $1,189.0$ & $1,898.0$ & $2,672.0$ \\
Net benefit & $\mathbf{1 , 0 1 7 . 1}$ & $\mathbf{4 , 5 9 4 . 2}$ & $\mathbf{8 , 1 0 6 . 3}$ & $\mathbf{9 9 7 . 9}$ & $\mathbf{4 , 5 4 5 . 8}$ & $\mathbf{8 , 0 2 8 . 7}$ \\
Benefit if labor cost is not included & $\mathbf{1 , 9 2 7 . 1}$ & $\mathbf{5 , 7 3 4 . 2}$ & $\mathbf{9 , 4 7 6 . 3}$ & $\mathbf{1 , 9 0 7 . 9}$ & $\mathbf{5 , 6 8 5 . 8}$ & $\mathbf{9 , 3 9 8 . 7}$ \\
\hline
\end{tabular}

Source: survey 2002

If $100 \%$ of grass is purchased, income from dairy production in two communes Phudong and Vinhngoc are almost equivalent. In this case, income from dairy production is approximately equal to income from crop cultivation in household with 1 cow. Farmers can get an income of nearly VND 6 million if they rear 2 cows and 10 millions per year if they rear 3 cows.

In the case of self-supplied grass, farmers get a bigger income. Feed cost accounts for about $47 \%$ of total variable cost, less than $74.6 \%$ of the other case in farm size of 1 . Farmers will save approximately VND 1 million $(3,022.1-1,927.1)$ per year from self-supplying grass for this farm size. In larger farm size, it is more profitable. Farmers could get VND 9.749 million or 16.411 million from dairy production with 2 or 3 heads/size, respectively (table 3.16 ).

In order to compare with crop cultivation sector, income from crop cultivation will also be calculated (table 3.17). About 175 man-days will be needed to cultivate 4.5 saos of paddy land and 2.1 saos of alluvial land. Return to labor from crop cultivation is about VND 11,428 per man-day. Total man-days is 91 if grass is purchased and 185 if grass is self-supplied (table 3.15 16), so rearing one cow brings farmers VND 21,177/man-day 
Table 3.16. Cost-benefit of dairy production with self-supplied grass

Unit: Thous. VND

\begin{tabular}{lrrrrrr}
\hline Items & \multicolumn{3}{c}{ Phudong } & \multicolumn{3}{c}{ Vinhngoc } \\
\hline & 1 cow & 2 cows & 3 cows & 1 cow & 2 cows & 3 cows \\
\hline Benefit & $\mathbf{1 4 , 8 5 1 . 5}$ & $\mathbf{2 9 , 7 0 3 . 0}$ & $\mathbf{4 4 , 5 5 4 . 5}$ & $\mathbf{1 4 , 8 5 1 . 5}$ & $\mathbf{2 9 , 7 0 3 . 0}$ & $\mathbf{4 4 , 5 5 4 . 5}$ \\
Fresh milk & $12,291.5$ & $24,583.0$ & $36,874.5$ & $12,291.5$ & $24,583.0$ & $36,874.5$ \\
Calf & $2,200.0$ & $4,400.0$ & $6,600.0$ & $2,200.0$ & $4,400.0$ & $6,600.0$ \\
Manure & 360.0 & 480.0 & 600.0 & 360.0 & 480.0 & 600.0 \\
Cost & $\mathbf{1 3 , 6 7 9 . 4}$ & $\mathbf{2 2 , 3 7 3 . 8}$ & $\mathbf{3 1 , 1 4 3 . 2}$ & $\mathbf{1 0 , 8 7 3 . 6}$ & $\mathbf{1 9 , 5 9 7 . 2}$ & $\mathbf{2 8 , 3 9 5 . 8}$ \\
Fixed cost & $\mathbf{3 , 5 0 0 . 0}$ & $\mathbf{5 , 6 0 0 . 0}$ & $\mathbf{7 , 7 0 0 . 0}$ & $\mathbf{2 , 5 0 0 . 0}$ & $\mathbf{4 , 6 0 0 . 0}$ & $\mathbf{6 , 7 0 0 . 0}$ \\
Depreciation of cow & $2,000.0$ & $4,000.0$ & $6,000.0$ & $2,000.0$ & $4,000.0$ & $6,000.0$ \\
Depreciation of fixed assest & $1,500.0$ & $1,600.0$ & $1,700.0$ & 500.0 & 600.0 & 700.0 \\
Variable cost & $\mathbf{1 0 , 1 7 9 . 4}$ & $\mathbf{1 6 , 7 7 3 . 8}$ & $\mathbf{2 3 , 4 4 3 . 2}$ & $\mathbf{8 , 3 7 3 . 6}$ & $\mathbf{1 4 , 9 9 7 . 2}$ & $\mathbf{2 1 , 6 9 5 . 8}$ \\
Feed cost & $4,795.4$ & $9,590.8$ & $14,386.2$ & $4,824.6$ & $9,649.2$ & $14,473.8$ \\
Labor cost & $1,850.0$ & $2,420.0$ & $3,000.0$ & $1,850.0$ & $2,420.0$ & $3,000.0$ \\
Breeding and veterinary cost & 520.0 & $1,040.0$ & $1,560.0$ & 510.0 & $1,030.0$ & $1,550.0$ \\
Miscellaneous costs & $3,014.0$ & $3,723.0$ & $4,497.0$ & $1,189.0$ & $1,898.0$ & $2,672.0$ \\
Net benefit & $\mathbf{1 , 1 7 2 . 1}$ & $\mathbf{7 , 3 2 9 . 2}$ & $\mathbf{1 3 , 4 1 1 . 3}$ & $\mathbf{3 , 9 7 7 . 9}$ & $\mathbf{1 0 , 1 0 5 . 8}$ & $\mathbf{1 6 , 1 5 8 . 7}$ \\
Benefit if labor cost is not included & $\mathbf{3 , 0 2 2 . 1}$ & $\mathbf{9 , 7 4 9 . 2}$ & $\mathbf{1 6 , 4 1 1 . 3}$ & $\mathbf{5 , 8 2 7 . 9}$ & $\mathbf{1 2 , 5 2 5 . 8}$ & $\mathbf{1 9 , 1 5 8 . 7}$ \\
\hline
\end{tabular}

Source: survey 2002

Table 3.17. Cost-benefit of crop cultivation in the study area

\begin{tabular}{|c|c|c|c|c|c|c|c|c|c|c|}
\hline \multirow[b]{2}{*}{ Items } & \multirow[b]{2}{*}{ Unit } & \multirow{2}{*}{$\begin{array}{l}\text { Price } \\
\text { (VND) }\end{array}$} & \multicolumn{2}{|c|}{ Spring rice } & \multicolumn{2}{|c|}{ Autumn rice } & \multicolumn{2}{|c|}{ Winter maize } & \multicolumn{2}{|c|}{ Maize on alluvial land } \\
\hline & & & Quantity & $\begin{array}{l}\text { Value } \\
\text { (VND) }\end{array}$ & Quantity & $\begin{array}{l}\text { Value } \\
\text { (VND) }\end{array}$ & Quantity & $\begin{array}{l}\text { Value } \\
\text { (VND) }\end{array}$ & Quantity & $\begin{array}{l}\text { Value } \\
\text { (VND) }\end{array}$ \\
\hline \multicolumn{2}{|l|}{ Total income/sao } & 1,800 & 160 & 288,000 & 150 & 270,000 & 100 & 250,000 & 100 & 250,000 \\
\hline \multicolumn{11}{|l|}{ Cost/sao } \\
\hline Labour cost & man/day & 10,000 & 10 & 100,000 & 10 & 100,000 & 10 & 100,000 & 10 & 100,000 \\
\hline Variety & $\mathrm{kg}$ & 2,160 & 2 & 4,320 & 2 & 4,320 & 0 & 750 & 0 & 750 \\
\hline Manure & $\mathrm{kg}$ & 50 & 200 & 10,000 & 200 & 10,000 & 200 & 10,000 & 200 & 10,000 \\
\hline Nitrogen & $\mathrm{kg}$ & 2,300 & 8 & 18,400 & 8 & 18,400 & 2 & 4,600 & 1 & 2,300 \\
\hline Phosphorus & $\mathrm{kg}$ & 1,100 & 10 & 11,000 & 10 & 11,000 & 10 & 11,000 & 8 & 8,800 \\
\hline Postassium & $\mathrm{kg}$ & 2,500 & 3 & 7,500 & 3 & 7,500 & 2 & 5,000 & 1 & 2,500 \\
\hline Pestiside & & & & 7,000 & & 7,000 & & 0 & & 0 \\
\hline Machine cost & & & & 50,000 & & 50,000 & & 20,000 & & . \\
\hline Irrigation cost & $\mathrm{kg}$ & 1,800 & 11 & 19,800 & 9 & 16,200 & & 0 & & 0 \\
\hline $\operatorname{Tax}$ & $\mathrm{kg}$ & 1,800 & 8 & 14,400 & 8 & 14,400 & 0 & 0 & 6 & 86,400 \\
\hline Other cost & & & & 30,000 & & 30,000 & & 20,000 & & 20,000 \\
\hline Total cost/sao & \multicolumn{2}{|l|}{ VND } & \multicolumn{2}{|r|}{272,420} & \multicolumn{2}{|r|}{268,820} & \multicolumn{2}{|r|}{171,350} & \multicolumn{2}{|r|}{230,750} \\
\hline Net befefit/sao & \multicolumn{2}{|l|}{ VND } & & 15,580 & & 1,180 & \multicolumn{2}{|r|}{78,650} & \multicolumn{2}{|r|}{19,250} \\
\hline \multirow{2}{*}{\multicolumn{5}{|c|}{$\begin{array}{l}\text { Income/sao if labor cost is not included } \\
\text { Subtotal/4.5 sao of paddy land and } 2.1 \text { sao of }\end{array}$}} & \multirow{2}{*}{\multicolumn{2}{|c|}{101,180}} & \multirow{2}{*}{\multicolumn{2}{|c|}{178,650}} & \multicolumn{2}{|r|}{119,250} \\
\hline & & & & & & & & & & \\
\hline \multicolumn{4}{|c|}{$\begin{array}{l}\text { Subtotal } / 4.5 \text { sao of paddy land and } 2.1 \text { sao of } \\
\text { alluvial land }\end{array}$} & 520,110 & \multirow{2}{*}{\multicolumn{2}{|c|}{455,310}} & \multirow{2}{*}{\multicolumn{2}{|c|}{803,925}} & \multirow{2}{*}{\multicolumn{2}{|c|}{250,425}} \\
\hline \multicolumn{4}{|c|}{ Average income from crop cultivation/HH } & $, 029,770$ & & & & & & \\
\hline
\end{tabular}

Source: survey 2002 
or VND 16,336/man-day, respectively. Therefore, farmers should invest more in dairy production. But how much they should invest in will be depend on their ability and available resources.

\subsection{Effects of dairy farming on environment}

Due to the close distance between living house and cow barn, air environment is becoming smelly inside dairy farm households. Farmers discharge cow excretion, firstly, into the bio-digesters if they have. The rest or all is accumulated in the paddy field for rice cultivation or in somewhere near their house for selling. The fresh excretion is exposed when it was carried from one place to another, making the road dirty and the air polluted. Most of dairy farmers discharge waste water into the public sewage system along alleys of the village. This sewage is also exposed. During the survey period, it was seen that the sewage had always been in the full situation. It is the biggest cause contributing to environment pollution, including water, soil and air pollution.

No one can deny the critical role of dairy production in improving people's living standard in suburb of Hanoi, but not $100 \%$ of population here realizes its negative side. High income from dairy production is connected closely with loss. It is very easy for farmers to see the visible profit inflow but it takes a long time for them to understand the invisible benefit outflow. That is uncompensated loss for their health. Due to the higher cow density in Phudong, $75 \%$ of households here acknowledge that they are living in the polluted environment, while this figure in Vinhngoc is $10 \%$ only. For these farmers, however, environment problem is not the first priority to solve. The pollution would be more serious if the authorities would not take appropriate actions right now.

\subsection{Dairy farmers with cooperatives}

Dairy cooperative is not existent in Vinhngoc but in Phudong. The definition activity of dairy cooperative, however, is not familiar to dairy farmers here. Even some of them have not noted the existence of Phudong dairy cooperative. Total number of dairy farming cooperative members are 58, accounting for $12.61 \%$ of total dairy farmers in 2002 (table 3.18). Of which, only 30 members, equivalent to $6.5 \%$ of total farmers, were selling their raw milk to the cooperative. What were the reasons for these modest percentages?

Firstly, dairy farmers found no difference between being members and non-members of dairy cooperative. They obtained the same raw milk price to whomever they sell their raw milk: cooperative or private collectors. Secondly, they are required to contribute a share of $300,000 \mathrm{VND}$ to join cooperative. They known they would get an inconsiderable

Table 3.18. Organization of Phudong Dairy Cooperative

\begin{tabular}{lcccccc}
\hline & Unit & At first & 1999 & 2000 & 2001 & 2002 \\
Total Members of Phudong & pers. & 18 & 48 & 56 & 58 & 63 \\
Dairy farming members & pers. & 13 & 43 & 51 & 53 & 58 \\
Dairy HH in Phudong & HH & & 188 & 280 & 419 & 460 \\
Percentage of cooperative Mem. & $\%$ & & 22.87 & 18.21 & 12.65 & 12.61 \\
\hline
\end{tabular}

Source: survey 2002 
return from their share every year, and they fear losing this share if the dairy cooperative were collapsed. Thirdly, the private collectors are willing to lend farmers capital whenever they need, and to get repayment by fresh milk. This is an advantage that the dairy cooperative has failed to supply. Finally, dairy farmer preferred to sell their milk to private collectors because collectors are quite flexible. Unlike cooperative with a fixed time of procurement, private collectors accept to buy milk at any time and regardless of milk quality. Even though farmers had to bear the risk, the farmers felt pleased with collectors when collectors tried to market the poor quality milk for farmers.

Responding to the question "do you know anythings about the new cooperative law?", $68 \%$ and $75 \%$ of sampled dairy farmers in Phudong and Vinhngoc answered that they had no idea. The same percentages of farmers said they were not interested in new cooperative law and dairy cooperative as well.

The survey reveals that, there are some dairy farmers wishing to join dairy cooperative, but they need some kinds of movement or encouragement from cooperative. It means that the dairy cooperative has not taken any action to incorporate new members. All other farmers said they would follow their neighbors. They will join dairy cooperative if the majority of dairy farmers do so.

Most farmers, irrespective of members or non-members of Phudong dairy cooperative, have been waiting for a strong cooperative to support them in many aspects, such as ensuring milk outlet, increasing milk price, lending them capital in long term, supplying inputs and veterinary services, processing milk products, and training them in the new techniques in dairy production.

\section{LIMITING FACTORS OF DAIRY PRODUCTION DEVELOPMENT IN HANOI}

Apart from weather, the most favorable condition deciding the existence and development of dairy production of Hanoi in particular and of Vietnam in general is the poten-

Table 4.1. Dairy farmers ranking problems facing them

Unit: \%

\begin{tabular}{|c|c|c|c|c|c|c|c|c|c|c|c|c|c|c|}
\hline \multirow[t]{2}{*}{ Kinds of problems } & \multicolumn{7}{|c|}{ Phudong } & \multicolumn{7}{|c|}{ Vinhngoc } \\
\hline & 1 & 2 & 3 & 4 & 5 & 6 & 7 & 1 & 2 & 3 & 4 & 5 & 6 & 7 \\
\hline Investment capital & 12.0 & 8.0 & & 4.0 & & & & 50.5 & 25.0 & & & & & \\
\hline Breeding and disease prob. & 28.0 & 60.0 & 4.0 & & & & & 16.7 & 41.7 & 16.7 & & & & \\
\hline Shortage of land and fodder & 56.0 & 12.0 & 16.0 & & & & & 25.0 & 8.3 & 33.3 & 8.3 & 8.3 & & \\
\hline Limitation of knowledge & 4.0 & & 12.0 & 16.0 & & 4.0 & & & 16.7 & 8.3 & 33.3 & & & \\
\hline High feed cost & & 4.0 & 8.0 & 8.0 & & 4.0 & 4.0 & 8.3 & & & 8.3 & & & \\
\hline Low milk price & & 4.0 & 8.0 & & 4.0 & & & & & 25.0 & & & & \\
\hline Milk outlet & & & 4.0 & ) & & & & & 8.3 & & & & & \\
\hline Environmental problems & & 8.0 & 20.0 & 28.0 & 16.0 & 8.0 & & & & & 8.3 & & & \\
\hline Social problems & & & 4.0 & 24.0 & 16.0 & 4.0 & 4.0 & & & & & & & \\
\hline Policy problems & & & 4.0 & & & & 4.0 & & & & & & & \\
\hline & 100 & 96 & 80 & 80 & 36 & 20 & 12 & 100 & 100 & 83 & 58 & 8 & & \\
\hline
\end{tabular}

Source: survey 2002 
tial market for fresh milk. Dairy farmers feel free about milk outlet. All fresh milk has been bought by milk factories such as VINAMILK or NESTLE companies. According to dairy farmers in Hanoi, milk price was stable and much more profitable compared to rice price. Why haven't they invested in dairy production or in enlarging the dairy farm size?

The answer is that dairy farmers in Hanoi have been facing some outstanding problems that restrain them from starting and expanding dairy production. In the survey, farmers were asked to rank the problems in a decreasing order of difficulty level from 1 to 7 (table 4.1). According to the result, the three biggest problems are problem of shortage of green fodder, problem of lacking of capital, and problem of breeding and cow diseases. There is, however, a small difference about difficulties facing dairy farmers between Phudong and Vinhngoc.

\subsection{Shortage of capital}

Many dairy farmers in Phudong wish to use credit for building bio-digester, while most of farmers in Vinhngoc need money to start and develop dairy production. High return from dairy production is required against a big cost compared to rice production, especially initial investment cost to buy cows. Cow price ranges from 15 mill. to 25 mill. VND. About $80 \%$ of farmers had to use credit to start rearing cows. Lenders never or cannot lend a large amount of money to farmers, therefore farmers have to seek credit from different sources. Unfortunately, there are some reasons preventing farmers from obtaining loans. Those are short-term duration, small amount of loan, high interest rate if borrowing from lenders and complex procedure if borrowing from Women Union. Another reason is risk. Most of the farmers, especially non-dairy farmers are worried that if their only cow died, they got nothing but being debtor. This explained why majority of households still keep enterprise of rice.

\subsection{Shortage of green fodder}

The most serious difficulty of farmers in Phudong was shortage of green fodder, while that was capital in Vinhngoc. Suppose that household's labor force is remaining under-employed, then green fodder and capital are the key inputs deciding dairy farm

size. If green fodder source is uniquely based on collecting natural grass, without hiring laborer, dairy farmers won't be able to collect enough grass for their cows in the dry season, especially in the severe weather days. Shortage of green fodder is not only in terms of quantity but also in term of quality. Different kinds of natural greed fodder were fed to dairy cow; leading to the disordered digestion that damage cow health. Farmers could enlarge their dairy farm size if they had enough spare fodder for cow during harvesting or severe climate days (Paul Pozy, Khai, Quang 2000).

About $88 \%$ of households in Phudong and $42 \%$ of households in Vinhngoc wish to rent-in more land to grow grass, even though land rent was considered to be expensive. Due to the limited land resource, $84 \%$ and $75 \%$ of dairy households in Phudong and Vinhngoc are willing to grow grass in stead of rice if it is possible. But it is impossible now because of land policy of the commune. If they grow grass in the paddy field then rats from grass plot will damage rice of non-dairy farmers in the surrounding plots. 


\subsection{Breeding and veterinary services}

The second biggest problem facing both dairy farmers in Phudong and Vinhngoc, which is relating to technical specialty, is problem of breeding and cow diseases. Experienced farmers can treat some simple cow diseases, such as diarrhea, dyspepsia. Most of them need veterinarian for other kinds of diseases. Farmers haven't got any idea about medicine used by veterinarian. They said veterinarians have never shown them the labels. Even if veterinarian did, farmers couldn't remember the foreign names of medicine. Farmers have no choice except buying medicine of veterinarian. Cost of treatment, sometimes, was not determined by the quality of medicine but it dependent upon the value, the milk yield, of sick cows. There is one veterinarian in each commune. In farmer's opinion, veterinarian's experience was good enough to do breeding and to treat cow diseases. Problem is in that breeding and treatment was done in time or not. With total 2,158 cows in Phudong and nearly 100 cows in Vinhngoc, veterinarian was unable to serve all cows if more than one dairy farmer need him at the same time. Therefore farmers sometimes had to ask veterinarians from Hanoi Agricultural University for help. It was recorded that veterinarian in Phudong was unenthusiastic. Many cows have died and many times of breeding have failed because of veterinarian's late treatments. It will be much better if there are some more veterinarians working in a competitive environment.

\subsection{Other limiting factors}

Dairy farmers in Phudong are facing many other urgent matters in comparison with dairy farmers in Vinhngoc. Dairy farmers without bio-digester were criticized by non-dairy farmers because of polluting environment. This caused some conflicts among people in the village. Some farmers report that price of feed is high. In addition, the protein-rich feed sources are not available. Moreover, $25 \%$ of dairy farmers in Vinhngoc are worrying about milk price because it has recently been decreasing. They do not know why their milk quality has been becoming low even though they keep the ration unchanged. Some dairy farmers suspect the test result of milk quality analyzed by collectors. They expect another receiving station will be installed by other one in the village, so that they can obtain a competitive price (Khai, Quang 1999).

\section{CONCLUSIONS AND RECOMMENDATIONS}

Recently, Hanoi city has made a big effort in dairy production development. It has greatly contributed to the success of Vietnam-Belgium dairy project in the suburb. As results, total number of dairy households increased to 660 , and total number of cows increased to 1650 heads in 2001. High dairy income has improved farmer's living standard. However, based on this study, some recommendations should be made to expand and develop dairy production in a sustainable way.

1. Master plan of land use should be revised as soon as possible. We should facilitate dairy farmers to freely grow grass on their allocated land without any complaining from rice-growing farmers. Many people will be willing to invest more in dairy production if they have opportunities to cultivate grass instead of rice.

2 . The governments at various levels should help farmers accessing to credit in many different ways, such as simplifying procedures, increasing loan amount with 
longer duration and low interest rate. Farmers should actively seek credit for themselves. Cooperation between milk factories and dairy farmers is one measure to adjust demand and supply of raw milk. Through a contract, dairy farmers can borrow money from milk factory and can pay back by raw milk.

3. Concerned government agents or organizations should pay attention to supply good dairy input services, especially breeding and veterinary services. Investing a big amount of money on dairy production, farmers want to buy a disease-resistant and high milk-yield-cow. Farmers expect high quality centers of cow breeds will be available for them. Veterinary network should be strengthened. Training and encouragement should be given to veterinarians to help farmers in an effective way.

4. New dairy cooperatives should be established. Activities of the existing dairy cooperatives should be extended and strengthened including insurance service to make dairy cooperative helpful and responsible for all dairy activities. Network of milk receiving stations should be organized and managed by dairy cooperatives in order to ensure stable and profitable milk price for dairy farmers.

5. Extension programs should be practiced frequently to train new dairy farmers in basic knowledge to start rearing cows, and to disseminate experiences and to introduce new advanced technologies to all dairy farmers.

\section{REFERENCES}

General Statistical Office (GSO) 2002 Statistical Yearbook 2001. Statistical Publishing House, Hanoi. Hanoi Statistical Office 2002 Hanoi Statistical Yearbook. Statistical Publishing House, Hanoi.

International Food Policy Research Institute (IFPRI) 2001 Policy Option for Using Livestock to Promote Rural Income Diversification and Growth in Viet Nam, Final Report, Volume 1: TEXT, chapter 1, PP. 1-26.

Khai, Quang 1999 Collecting raw milk in Hanoi and some related problems Livestock science and technologies Journal. 12, 30-31. Agricultural Publishing House, Hanoi (in Vietnamese).

Ministry of Agriculture and Rural Development (MARD) 2001 Draft of project on developing milk production in Vietnam from 2000 to 2010. In "Report of the Japanese technical cooperation for the project for the improvement of cattle artificial insemination technology" JICA, Tokyo, PP. 55-74.

Nguyen, Cong Tan (Deputy Prime Minister) 2001 Decision of Prime Minister No. 167/2001/QD-TTg Measures and Policies for milking cow development in Vietnam for period 2001-2010 The Government of Vietnam, Hanoi, $26^{\text {th }}$ October.

Paul Pozy, Khai, Quang 2000 The situation of dairy production in dairy households in suburb of Hanoi after 3 years implementing Vietnam-Belgium cooperation project. Livestock science and technologies Journal. 10, 12-13. Agricultural Publishing House, Hanoi (in Vietnamese).

Paul Pozy, Ban 2001 Techniques of ensiling green fodder at dairy households Agricultural Publishing House, Hanoi (in Vietnamese).

Phan, Van Khai (Prime Minister) 2000 RESOLUTION No. 09/2000/NQ-CP OF JUNE 15, 2000 ON A NUMBER OF UNDERTAKINGS AND POLICIES ON ECONOMIC RESTRUCTURING AND CONSUMPTION OF FARM PRODUCE OFFICIAL GAZETTE (VIETNAM), NO. 26 (15-7-2000), PP. 13-18

Thuong N. V. 1995 Some results of study of beef and dairy cattle in Vietnam Agricultural Publishing House, Hanoi (in Vietnamese). 